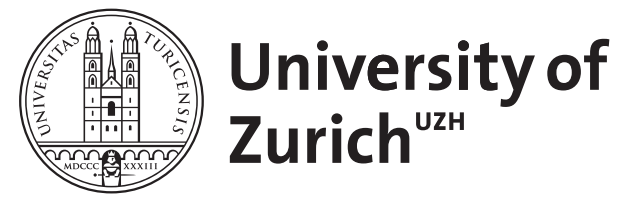

Toothless tigers? A commentary on Alec Murphy's 'Trapped in the Logic of the Modern State System?'

Müller, Martin

DOI: https://doi.org/10.1080/14650045.2012.748659

Posted at the Zurich Open Repository and Archive, University of Zurich ZORA URL: https://doi.org/10.5167/uzh-83888

Journal Article

Published Version

Originally published at:

Müller, Martin (2013). Toothless tigers? A commentary on Alec Murphy's 'Trapped in the Logic of the Modern State System?'. Geopolitics, 18(3):724-729.

DOI: https://doi.org/10.1080/14650045.2012.748659 


\title{
COMMENTARY
}

\section{Toothless Tigers? A Commentary on Alec Murphy's 'Trapped in the Logic of the Modern State System?'}

\author{
MARTIN MÜLLER \\ Universität St. Gallen, Switzerland, and Goethe-Universität Frankfurt, Germany
}

\section{THE EU - SUPRA-STATE OR POSTMODERN POLITICAL FORM?}

In February 2012 the European Commission released a video that was intended to promote the idea of European union among younger people. ${ }^{1}$ It shows a white woman, dressed in a golden jumpsuit, that is threatened by three men preparing to fight her. First a man, ostensibly from East Asia, jumps down in front of her performing Kung Fu. Then a practitioner of Kalaripayattu, a southern Indian martial art, levitates towards her brandishing a sabre and finally a black man cartwheels in, menacing the woman with Capoeira moves. The woman stays calm, splits into twelve versions of herself to surround the assailants, who then vanish as the twelve women turn into the twelve stars of the EU flag, accompanied by the message "The more we are, the stronger we are". The video, an attempt at viral communication, was retracted a few days after it was released - for obvious reasons. Propagating racialised threats to Europe, it is a thinly veiled attempt at promoting European unity through stoking geopolitical fears of China, India and Brazil, making individuals stand in for whole states. Its message is in tune with what Alexander Murphy diagnoses in his paper: a view of the EU as a supra-state, which is in competition with other states, and the drawing of clear boundaries of who belongs there and who does not. ${ }^{2}$

Alexander Murphy's intervention comes at a critical juncture, when the $\mathrm{EU}$ is arguably at a watershed. It is on the cusp of a closer fiscal union, while at the same time much of what has been achieved over the past decades is at risk of falling to pieces. The potential shape of things to come with taking the

Address correspondence to Martin Müller, Universität St. Gallen, Varnbüelstr. 19, 9000 St. Gallen, Switzerland. E-mail: martin@martin-muller.net 
latter path has been foreshadowed in the cleavages of the last months: Britain wanting to go it alone, a string of political backsliding in Eastern European countries such as Hungary, Romania, Bulgaria and Serbia and a rekindling of nationalist sentiments. 'Divided we stand, united we fall' seems to be the new motto. The spring 2012 wave of the Pew Global Attitudes Project shows that in most European nations public opinion has swung against EU membership and that there is a significant degree of hostility between some member states such as Germany and Greece, with 49\% of Greeks holding a very unfavourable opinion of Germany. ${ }^{3}$

Coordinating fiscal policies in Brussels, however, would mean walking further down the road of the modernist territorial logic that Murphy identifies, ceding ever more powers of the national state to supra-national bodies. It would mean, Murphy argues, reinforcing the neat scalar hierarchies of supra-national, national, regional, local, at the expense of alternative metageographies of overlapping spatialities, such as those of transboundary networks or interregional cooperation arrangements, that would deserve the label of what John Ruggie claimed might be the first truly postmodern international political form'. ${ }^{4}$ In arguing for transcending traditional state spaces through non-state or extra-state forms of cooperation, Murphy situates his argument in the growing call for alternative models and visions of European integration among geographers, whether it is non-territorial metaphors of translation and mediation, a plea against containerisation and for more fluid shapes, an inclusive regional dialogue in the European neighbourhood or Europe as a post-national and multi-ethnic migrant space. ${ }^{5}$

It is hard to disagree on normative grounds with the vision Murphy sketches, for it is indeed an appealing one. But I would like to argue that we might be presented with a somewhat different picture if we look not only at the formal arrangements and the narrative on integration, but also at how these are practiced. ${ }^{6}$ There are three substantive aspects I would like to raise. First, much can be gained from viewing the scalar hierarchies in the EU as not quite as discrete and pre-ordained as they might appear, but as produced through multiple socio-material relations. Second, the geographies of the euro do not map onto a modern territorial logic in a straightforward fashion but keep overflowing the rigid EMU framework. Third, most regional initiatives tend to be toothless tigers and the potential ceding of power to the EU in the wake of the current crisis might, after all, be more conducive to European unity, both in a political and in a social sense.

\section{THE EU AS ALWAYS LOCAL}

Murphy points out that European Monetary Union (EMU) required national governments to divest themselves of decision-making power and centralise it at the supra-state level. This process involved surrendering sovereignty to 
reinforce the EU's capacity as a political-territorial actor and 'bringing into being a large-scale unit that looked and functioned increasingly like a state'. ${ }^{7}$ But if we look beyond the formal distribution of responsibilities, we might find that the scalar territorial logic is not quite as clear-cut as it might appear at first. Even the seemingly highest echelons of the European Commission in Brussels or the ECB in Frankfurt are and in fact have to be connected to, say, the bank clerk in the small provincial town of Kößlarn in Bavaria. These connections are, for example, effected through technology, such as software for financial markets, that governs and regulates flows of capital and extends the power of the ECB across space. But the bank clerk is also connected to his colleague in the neighbouring branch in Rotthalmünster, because they play in the same football team. And after the game they sometimes talk about how they assess the creditworthiness of clients and the loopholes that the current rules offer to still accommodate those clients who are going through rough patches at the moment, bypassing some of the hierarchical arrangements.

Instead of viewing the EU as carved up in multiple levels, then, one could adopt an alternative perspective and ask how these levels are the product of a larger actor-network, despite the formal subordination that may exist. I am taking my cue from Bruno Latour here, who suggests that all organisations, even those that look large and complex, are after all continuously local: 'If we wander about inside IBM, if we follow the chains of command of the Red Army, if we inquire in the corridors of the Ministry of Education, .... we never leave the local level. Could IBM be made up of a series of local interactions? The Red Army of an aggregate of conversations in the mess hall? The Ministry of Education of a mountain of pieces of paper?'8 Instead of taking the EU as one big organisation, one could ask how it is made up of multiple socio-material relations that need to be actualised again and again for it to emerge as an actor and how scales are enacted (or perhaps not) in this process.?

\section{THE OVERFLOWING GEOGRAPHIES OF THE EURO}

The usage of the euro is a case in point that illustrates how a product of the modern territorial system overflows the hierarchical state space that created and regulates it. Some of this usage is authorised by the European Central Bank, such as in Monaco, the Vatican, Andorra and San Marino, which have concluded monetary agreements granting them issuing rights. Another variant is the pegging of a currency to the euro, as is the case with Bulgaria, Morocco and several other countries.

Of much greater interest here are those cases, however, where the euro is used without official sanctioning of the ECB, called euroisation. Kosovo and Montenegro, for example, use the euro as a de facto domestic currency. 


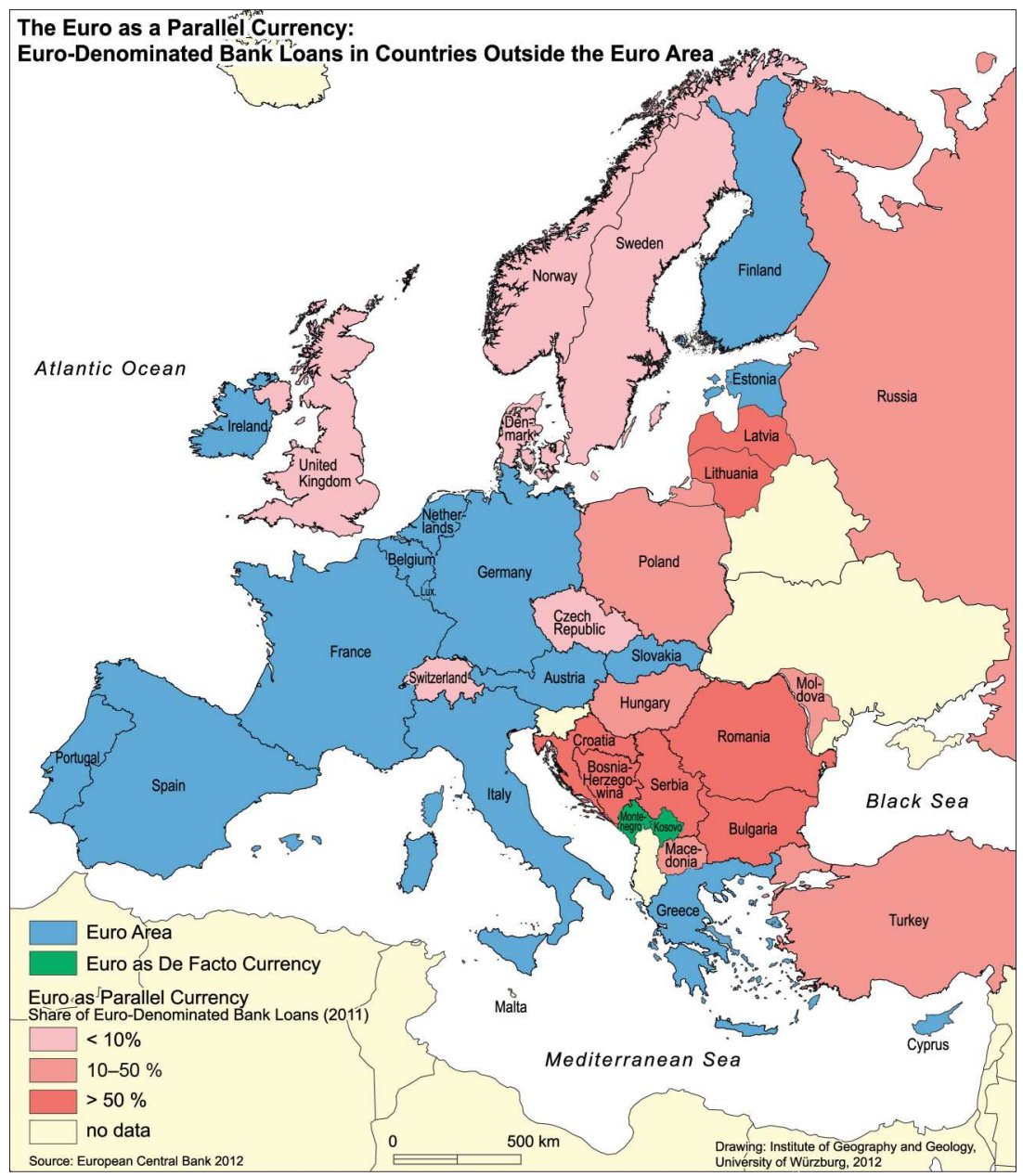

FIGURE 1 The euro as a parallel and de facto currency: Euro-denominated bank loans in countries outside the euro area (color figure available online).

In many other countries in Central and Eastern Europe it functions as a parallel currency to local currencies, either in cash transactions or for assets and liabilities (see Figure 1). Estimates put the amount of euro banknotes circulating outside the eurozone in 2011 at between 20 and 25\% of the total, ${ }^{10}$ most of them in countries adjacent to the EU. In 2006, residents of Croatia held an annual average of more than EUR 500 per capita in cash. ${ }^{11}$ In countries like Croatia or Serbia, more than half of all loans are denominated in euros, with even higher shares in Latvia and Lithuania. ${ }^{12}$ Despite recent dips in confidence, the euro is still more trusted than the local currencies and therefore often preferred in financial transactions because of stable inflation expectations. 
A significant part of the usage of the euro thus falls outside the jurisdiction of the ECB, but also outside the reach of the monetary policies of the affected countries, in practice overturning the rigid scalar hierarchies that the EMU mandates. These unintended overflows, as Michel Callon would call them, ${ }^{13}$ frequently bypass official channels and bring into being informal networks, integrating individuals into the eurozone where the respective countries are often unlikely to join the EMU. The effects of these overflows tend to undermine state authority: often tied to informal economic activities, they facilitate tax evasion and rent seeking and weaken governments' capacity to engage in effective macroeconomic interventions. On the other hand, however, the stability of the euro makes it more suitable for storing or transferring value and engaging in long-term economic planning, which is often difficult with the volatile inflation of local currencies.

\section{TOOTHLESS TIGERS}

The overflows of the euro outside the territorial system of the EMU have had a significant impact on people's everyday lives in many neighbouring countries. This is much less the case with most cross-border initiatives in the EU, which tend to be rather toothless tigers. Murphy names a number of them as examples of a non-territorial metageographical imagination: the Four Motors Agreement, the Alliance of European Lawyers in Brussels, Erasmus, ESPON and CORINE. Ask a representative sample of EU citizens what part of the EU has had the largest impact on their lives and it is likely that the euro or food regulation dictating the curvature of cucumbers will come to mind first, whereas the Four Motors, ESPON or the Alliance of European Lawyers are more likely to draw quizzical looks.

Take INTERREG, the flagship of European cross-border spatial development and territorial cooperation, which is designed to diminish the influence of national borders and create greater European cohesion. With a budget of EUR 7.8 billion for the period from 2007 to 2013 it may look like a heavyweight, but it in fact receives only $2.6 \%$ of the total funds for regional policy, the rest being allocated to territorial development. What is more, the importance of territorial cooperation in spatial planning has been severely downgraded in the recent edition and much of the programme has been refocused on promoting jobs and growth instead of cooperation. One major reason for this might be the significant gap between the programmatic aim of promoting transborder development and planning and the moderate outcomes of INTERREG in this regard, which often enough follow particularist rationales. ${ }^{14}$

This is not to say that such initiatives are not important, but as long as they are not undergirded by the concomitant regulatory or prescriptive power, they run the danger of remaining toothless tigers. One could argue for 
the current euro crisis that its cause was too little instead of too much power given to the EU: one of the central design flaws of the euro, according to economists, is to attempt a currency union without a fiscal and political union that would help in coordinating budgeting, taxes, health care, labour policies and so on. Gaining such power, however, will require member states to cede it in the first place. Murphy is sceptical whether giving more power to the EU will produce greater unity. I believe it can, because it is likely to also create a greater shared sense of being affected by and responsible for the same policies, no matter whether you live in Frankfurt or on Korfu. It might help institutionalise a stronger awareness of being in the same boat - something that seems to be sorely missing from many discussions on whether or not Greece should exit the euro area. In a sense then, the current crisis might be the best thing that ever happened to the European project: it can become a catalyst for closer integration and in fact achieve something that, because of nationalist sentiments and particularist interests, our wildest dreams would not have allowed us to imagine just a few years ago.

\section{NOTES}

1. Available at YouTube, <http://www.youtube.com/watch?v=WQREDQjfzC4>, accessed 2 Aug. 2012.

2. Alexander Murphy, 'Trapped in the Logic of the Modern State System? European Integration in the Wake of the Financial Crisis', Geopolitics (present issue).

3. Pew Research Center, European Unity on the Rocks: Greeks and Germans at Polar Opposites. (Washington, DC: Pew Research Center 2012).

4. John Gerard Ruggie, 'Territoriality and Beyond: Problematizing Modernity in International Relations', International Organization 47/1 (1993) pp. 139-174.

5. These ideas were voiced respectively by Luiza Bialasiewicz and Claudio Minca, 'Old Europe, New Europe: For a Geopolitics of Translation', Area 37/4 (2005) pp. 365-372; Freerk Boedeltje and Henk van Houtum, 'The Abduction of Europe: A Plea for Less 'Unionism' and More Europe', Tijdschrift voor economische en sociale geografie 99/3 (2008) pp. 361-365; James W. Scott, 'The EU and 'Wider Europe': Toward an Alternative Geopolitics of Regional Cooperation?', Geopolitics 10/3 (2005) pp. 429-454; and Ash Amin, 'Multi-Ethnicity and the Idea of Europe', Theory, Culture \& Society 21/2 (2004) pp. 1-24.

6. Martin Müller, 'Reconsidering the Concept of Discourse for the Field of Critical Geopolitics: Towards Discourse as Language and Practice', Political Geography 27/3 (2008) pp. 322-338.

7. Murphy (note 2). p. xxxxx.

8. Bruno Latour, We Have Never Been Modern (Hemel Hempstead: Wheatsheaf 1993) p. 121.

9. Martin Müller, 'Opening the Black Box of the Organization: Socio-Material Practices of Geopolitical Ordering', Political Geography 31/6 (2012).

10. European Central Bank, The International Role of the Euro (Frankfurt: ECB 2012) p. 20. 2007) p. 57.

11. European Central Bank, Review of the International Role of the Euro (Frankfurt: ECB

12. European Central Bank (note 10) p. 76.

13. Michel Callon, The Laws of the Markets (Oxford: Wiley-Blackwell).

14. See Stefanie Dühr and Vincent Nadin, 'Europeanization through Transnational Cooperation? The Case of INTERREG IIIB North-West Europe', Planning, Practice E Research 22/3 (2007) pp. 373-394 for an insightful analysis. 